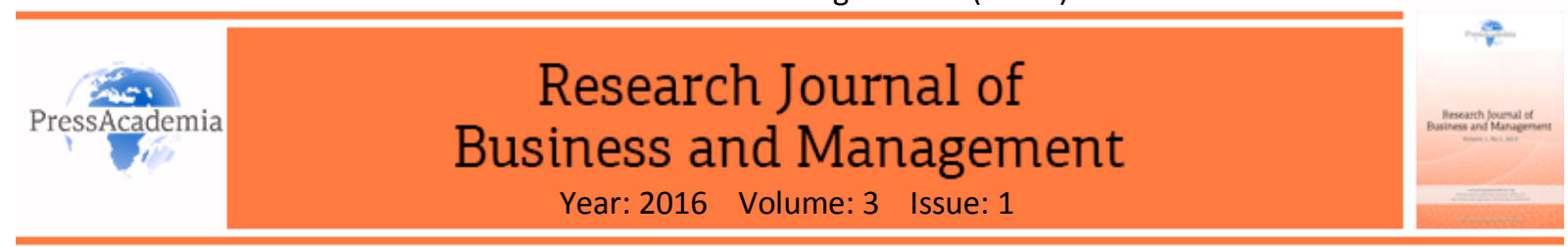

\title{
DOES DEMOGRAPHY MATTER IN NONVERBAL COMMUNICATION BETWEEN PHYSICIAN AND PATIENT
}

DOI: 10.17261/Pressacademia.2016116540

\author{
Indrianty Sudirman', Indahwaty Sidin ${ }^{2}$ \\ 'Hasanuddin University.indrianty_sudirman@yahoo.com \\ ${ }^{2}$ Hasanuddin University.indahusman@gmail.com
}

\begin{abstract}
Previous studies show that the effective nonverbal communication in therapeutic communication plays important role to influence the optimal level of patient's healthiness through patient's satisfaction due to asymmetry information between physician and patients. However, which variables of nonverbal communicationsthat are suitable to meet the need of different demography characteristics is still poorly understood. This research analyze the significances of each non-verbal communication variables consisting of artifact, haptic, kinesics, chronemics, proxemics, and vocalic to satisfy patients with different demography classification based on age, gender, ward type, ethnic, education, and occupation. The result shows that demography characteristics are really matter in explaining the influence of nonverbal communication variables to patients' satisfaction.
\end{abstract}

Keywords : Nonverbal communication, demography characteristics, patient's satisfaction. JEL Classification: D82, M30, M31

\section{INTRODUCTION}

Generally, therapeutic communication can be defined as an interaction between a health care professional and a patient that aims to enhance the patient's comfort, safety, trust, or health well-being. It is the basis of interactive relationships and affords opportunitiesto establish rapport, understand the client's experiences, formulate individualizedor client-centered interventions, and optimize health care resources. Therapeutic communication between nurses and patients have been widely studied and well documented. On the contrary, therapeutic communication between physician and patient has not been thoroughly explored while in fact it is very important in health services to achieve optimal healthy stage. Previous research papers indicate that quality communication among the client, health care providers, families, and other stakeholders can improve health care and help clients adapt to illness and adhere to interventions. Therapeutic communication, which refers to a healing or curative nurse-client interaction, allays stress in the nurse and client, particularly when they collaborate in the decision-making process for serious or life-threatening issues and informed consent (Lobb, Butow, Kenny, \& Tattersall, 1999; von Gunten, Ferris, \& Emanuel, 2000) ${ }^{1,2}$.

Therapeutic communication is a form of psychotherapy that uses verbal and nonverbal techniques in which through face-to-face communication, a clinician will use verbal and nonverbal techniques to assist patients with finding the root cause of a problem in a nonjudgmental way, while showing empathy and concern. The goal of therapeutic communication is to increase self-worth or decrease psychological distress by collecting information to determine the illness, assessing and modifying the behavior, and providing health education. The therapist will work on building a therapeutic relationship with patients and reassure that this type of therapy is client-centered. Therapeutic communication consists of verbal and non-verbal communication.

The most communication commonly used in health services is verbal communication because of its accuracy. Nevertheless not all of verbal messages can be easily understood by patients due to asymmetric information 
between physician and patient on medical knowledge. Most patientsusually have limited information about their illness and their treatment options. Patients with chronic illnesses that are supposed to have more access to such kind of information are usually more suffering from asymmetric information (Sudirman, 2012) . This $^{3}$ makes the nonverbal communication becoming more relevant as a complementary therapeutic communication in serving health services especially in convincing the patients.

In most cases health treatment environment could cause significant fear and uncertainty to the patients and their families. It could be understood if the patients and their families then relay on the observation of nonverbal as an instant tool to obtain information, even before the verbal interaction occurred. This may cause the patients and their families becoming very sensitive to nonverbal communication of professionals (Friedman, 1979) ${ }^{4}$.

Communication between patient and physician needs to be viewed in its entirety. The distinction between verbal and nonverbal communication is somewhat arbitrary. The purpose of this article is to focus attention on the nonverbal component of communication, because awareness of this aspect of our communication will lead to a greater understanding of our patients and ourselves and the messages we exchange. Nonverbal communication provides a way of communicating the emotional experience of illness that is often difficult, if not impossible, for the patient to verbalize. It allows health care providers to send messages of empathy and understanding and to communicate messages.

Several previous researchers found that nonverbal communication of physician significantly affected satisfactory level of patients during treatment in hospitals (Ambady et al, 2002; Griffith et al, 2003) ( $^{5,6}$ Good and effective communication quality between physician and patient will give a significant impact to patient satisfaction during recovery process. The satisfied patient would then have a tendency to be loyal and return to the same physician when needing health services in the future (Sudirman, 2002) ${ }^{7}$. However, the role of demography in moderating the influence of physician's nonverbal communication to patient's satisfaction is still poorly understood.

In order to comprehend on how to satisfy the patients, it is required to identify their wish, need, and hope by identifying the characteristics of each patient. Patients who are satisfied with hospital or physician health service will be loyal and return if they need health care service (Sudirman, 2012) ${ }^{8}$. This is primarily due to the sensitivity of patient to nonverbal communication which is varied depending on the characteristics of patient. However, the relationship between demography of patientsand clinicians during nonverbal therapeutic communication has been underexplored. Therefore, it is important to further analyze the influence of nonverbal communication of physician to the patient with respect to different perspectives of patient's demography.

In this study we intended to investigate the the role of demography in moderating the influence of physician's nonverbal communication to patient's satisfaction. Six types of nonverbal communication consisting of artifact, haptic, kinesics, chronemics, proxemics, and vocalic were analyzed with respect to different groups of patient demography using conceptual model of nonverbal communication to identify the dominant factors affecting patient satisfaction.

\section{LITERATURE SURVEY}

\subsection{Therapeutic Communication}

The concept of "therapeutic communication" refers to the process in which the physician, clinical doctor or nurse consciously influences or helps a patient to a better understanding through verbal or nonverbal communication. Therapeutic communication involves the use of specific strategies that encourage the patient to express feelings and ideas and that convey acceptance and respect.

Therapeutic communication is considered as one of quality indicators of health services in hospital that could alter the patient satisfaction. It is an effort to create a mutual understanding and trust through idea exchanges with words, symbols or messages that will lead to mutual relationship between physician and patient. Effective communication occurs when a message is delivered and understood as what sender's intention and then followed up an action by the receiver without any obstacles. 
In health services, physicians and patients play an important role as a source of information either as a sender or a receiver. Effective communication in the context of physician and patient relationship is a professional attitude of a physician to build safe, secured, and trust feelings of the patients. These attitudes have already been exposed since at the beginning of consultation, during consultation process, and at the end of consultation. The ability of physician to explore and exchange the information both verbally and nonverbally with patients, patient's families, societies, colleagues, and other different characteristic of professions is core competency should be possessed by a physician in Indonesia (KKI, 2012) ${ }^{9}$.

Patient behavior in accepting diagnosis is determined by a physician including curing treatment, self-treatment as well as paying attention and obeying the physician's advices depending on the effectiveness of therapeutic communication between physician. Such communication would also influence the therapy decision whether continued or terminated partially. Physician's feedbacks obtained from the result of communication is obtained from patient's reaction or response during diagnosis, patient's behavior in repeated visits, and patient's preference in choosing the curing.

According to Watson $(1988)^{10}$, many factors in the patient's background will influence the therapeutic communication process and the outcome of each interaction are as follows: (a) culture, (b) values (the beliefs and rules people live by), (c) social status, (d) emotional state (feelings that affect patterns of communication), (e) spiritual orientation, (f) internal experiences (such as the biological and psychological impact on how a person interprets life situations), (g) external events, (h) family socialization about communication, (i) relationships, (j) current context of relationship, and (k) content of message (such as sensitive or emotionally charged topics). Different characteristic of patient will give different reactions such that a physician needs to pay attention on the background of patients with respect to a demographic factor in developing communication.

\subsection{Verbal and Nonverbal Communication}

The most common form of communication used by physicians in delivering their messages is verbal communication. This is simply because the character of verbal communication is more accurate and punctuate. In verbal communication, words are used to express ideas or feelings to stimulate emotional responses or to describe object, observation, and memory. The advantage of verbal communication in face to face interaction is the possibility of direct response from each individual.

Despite the fact that verbal communications is more accurate and punctuate, it is not all of verbal messages given by physician could be caught and understood by patients. This is primarily due to asymmetric information on health knowledge between physician and patient. As a result, miscommunication could critically occur due to different characteristics and knowledge gaps between physician and patient, between a certain patient and another patient having different characteristic backgrounds. Therefore, nonverbal communication is required to express attitudes and behaviors to convince patients during curing process. Mehrabian(1972) ${ }^{11}$ following suggested that only $7 \%$ of message is sent through words, with remaining $93 \%$ sent nonverbal expressions (depending on author, verbal part goes up to 35\%).

Nonverbal communication is a transfer of a message without using words. Nonverbal communication includes body language, such as gestures, facial expressions, eye contact and posture. Touch is a nonverbal communication that not only indicates a person's feelings or level of comfort, but illustrates personality characteristics as well. A firm handshake or warm hug indicates something very different than a loose pat on the back or a timid handshake does. The sound of our voice, including pitch, tone and volume are also forms of non-verbal communication. The meaning behind someone's words is often entirely different than the literal translation, as is seen in instances of sarcasm and mockery. The clothing we wear and the way we design our living space are also forms of nonverbal communication that frequently shape people's judgments about others, regardless of whether or not the perceptions are true. However, the role of demography in moderating the influence of physician's nonverbal communication to patient's satisfaction is still poorly understood. Dale G. Leather ${ }^{12}$ pointed out the important of nonverbal, among others are the importance of nonverbal factors in determining the essence of interpersonal communication; feelings and emotions can be delivered in more accurate way; free from any fakes, lies, distortions, and multi-interpretations in delivering the intention of the 
message; containing meta-communicative functions that's required to achieve high quality communication; more efficient compared to verbal communication; and more accurate suggestive medias.

Morris (1977) in Liliweri (2004) ${ }^{13}$ described that nonverbal communication consists of the following types:

1. Object Communication (Artifact)

Dressing is the most common object communication although it is often considered as one form of stereotypes; but generally people are valued based on their dresses. About $65 \%$ of patients expect the physicians wear a white coat during consultation.

2. Touch (Haptic)

Haptic is the study of the study of communication by touch such as shake hand, grasping hand, kissing, touching back, stroking, hitting and others. The form of this communication is to deliver messages about goal or feeling of the sender. The feelings or emotions of the sender either positive or negative can emerge due to touching. In fact touching can give incredible effect in medication. Touching has a strong effect in delivering message as long as delivered in good and responsible manner. If the touching is conducted in an inconvenience way it will cause trust loss, anxiety, and hostility.

3. Chronemics

Chronemics refers to the study of how time affects communication. This can be classified into several different categories including biological, personal, physical, and cultural time. Time is used in precise duration for a particular activity and also punctuality in doing communication.

4. Body Movements (Kinesics)

Kinesics refers to the study of hand, arm, body and face movements for examples gestures, head movements and posture, eye contact, and facial expressions as nonverbal communication. Eye contact, facial expression, sign language, and attitude are types of body movements that used to substitute words to explain something, express feeling, and handle a conversation or to release a tense.

5. Proxemics

Proxemics is a distance between people when they are communicating or having a conversation, includingthe place or position that you are in.

6. Vocalic

Vocalic is nonverbal communication such as intonation, accent, swiftness in speaking, and others used during a conversation.

7. Environment

Environment is also used to send a certain command or instruction including distance, temperature, light, and color.

\subsection{Conceptual Framework}

The nonverbal communication of physician in delivering health services consists of artifact, haptic, kinesics, kronemics, proxemics, and vocalic considered as influence factors of patient satisfaction. The significance and level of each nonverbal communication variable to the patient satisfaction will be different in according to the characteristic of patient demography. Each variable of nonverbal communication will be analyzed with respect of age, education, type of health services, ethnics, and occupations. 
Figure 1. Conceptual Framework

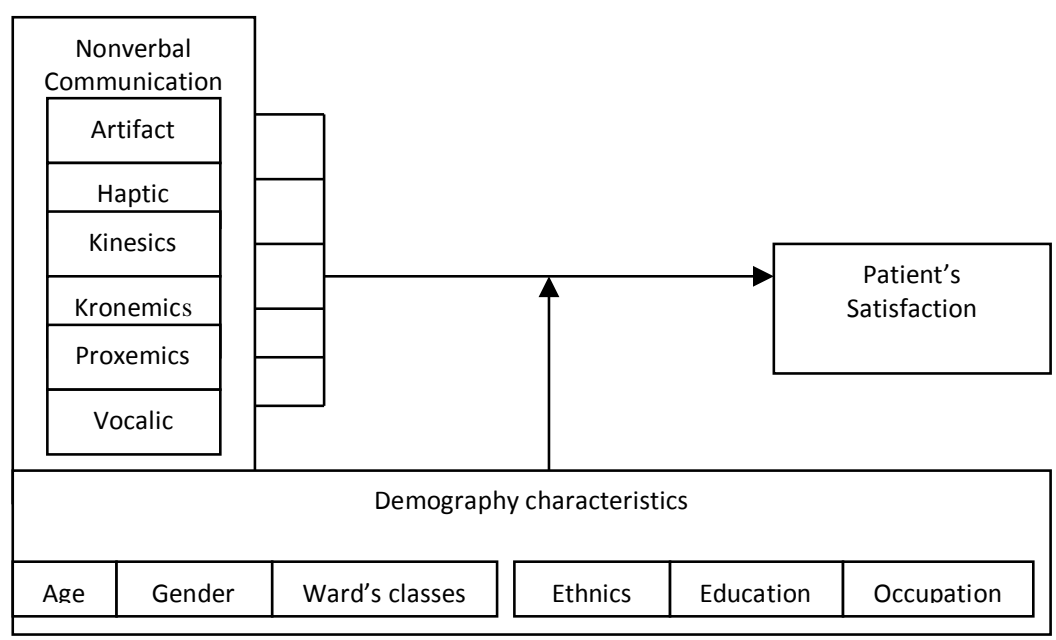

\section{DATA AND METHODOLOGY}

This research was carried out using a quantitative study with cross sectional design and questionnaire as the instrument of the research. The population was all the inpatient patients in fourteen hospitals in Makassar. The samples in this study were determined by proportional stratified random sampling so there were 420 respondents. The study conducted during June, 2015.

Physician's nonverbal communication will be considered as an independent variable and while patient's satisfaction is considered as a dependent variable in accordance of demographic characteristics of patient which is further categorized as age, gender, ward, ethnic, education level, and occupation.

Description of respondent wascategorized based on age, gender, ethnic, education, and occupation as illustrated in table 1 . Age category was divided into teenager $(<25$ years), adult ( $26-45$ years), elderly and oldest (> 46 years). Most of the respondents were in adult group $(56,2 \%)$. Another respondent's percentage were teenager $(19,5 \%)$, elderly and the oldest $(24,2,2 \%)$. Gender category was divided into male and female. Most respondents were female (66\%) while malecounted only $34 \%$. Ward category was divided into VIP class, first class, second class, and the third class. Most of the respondents were treated in the third class $(41,7 \%)$. Percentage for another class were VIP (12,9\%), first class $(15,2 \%)$, and the second class $(30,2 \%)$. Ethnic categories, however, were dominated by Bugis $(42,9 \%)$, then followed by Makassar (39,3\%). Another ethnics was Toraja, Mandar, Jawa and others (17,8\%). Education category was dominated by respondents in elementary school and high school $(65,2 \%)$ while respondents in higher education levels were $34,8 \%$. Occupation category was dominated by unemployed $(56,9 \%)$ in which civil servant counted for $67 \%$ while non civil servants counted about $27,1 \%$.

\section{Table 1: Respondent Characteristics}

\begin{tabular}{|l|l|l|l|}
\hline No & Demography Characteristic & N & $\%$ \\
\hline \multirow{4}{*}{1} & Age & 82 & 19,5 \\
\cline { 2 - 4 } & Teenager ( $<25$ years) & 236 & 56,2 \\
\cline { 2 - 4 } & Adult (26-45 years) & 102 & 24,2 \\
\cline { 2 - 4 } & Elderly and the oldest ( $>46$ years) & \multicolumn{2}{|l|}{} \\
\hline \multirow{2}{*}{2} & Gender & 143 & 34,0 \\
\cline { 2 - 4 } & Male & 277 & 66,0 \\
\cline { 2 - 4 } & Female & & \\
\hline 3 & Ward's classes & 54 & 12,9 \\
\cline { 2 - 4 } & VIP & \multicolumn{2}{|l}{} \\
\hline
\end{tabular}




\begin{tabular}{|l|l|l|l|}
\hline \multirow{4}{*}{} & First Class & 64 & 15,2 \\
\cline { 2 - 4 } & Second Class & 127 & 30,2 \\
\cline { 2 - 4 } & Third Class & 175 & 41,7 \\
\hline 4 & Ethnics & \multicolumn{2}{|l|}{} \\
\cline { 2 - 4 } & Bugis & 180 & 42,9 \\
\cline { 2 - 4 } & Makassar & 165 & 39,3 \\
\cline { 2 - 4 } & Others & 75 & 17,8 \\
\hline 5 & Education & \multicolumn{2}{|l}{} \\
\cline { 2 - 4 } & Elementary and High School & 274 & 65,2 \\
\cline { 2 - 4 } & Higher Education & 146 & 34,8 \\
\hline 6 & Occupation & 239 & 56,9 \\
\cline { 2 - 4 } & Unemployed & 67 & 16 \\
\cline { 2 - 4 } & Public Sector & 114 & 27,1 \\
\cline { 2 - 4 } & Private Sector & \multicolumn{2}{|l}{} \\
\hline
\end{tabular}

\section{EMPIRICAL FINDINGS}

Simultaneously, all variables of physician's nonverbal communication significantly influence patient's satisfaction as summarized in table 2 .

Table 2: Summary of Simultaneous Analysis Results

\begin{tabular}{|c|c|c|c|c|c|c|}
\hline \multicolumn{2}{|c|}{ Model } & \multirow{2}{*}{\begin{tabular}{|l}
$\begin{array}{l}\text { Sum of } \\
\text { Squares }\end{array}$ \\
4.811
\end{tabular}} & \multirow{2}{*}{$\frac{d f}{}$} & \multirow{2}{*}{\begin{tabular}{|l|} 
Mean Square \\
.802
\end{tabular}} & \multirow{2}{*}{\begin{tabular}{|l}
$\mathbf{F}$ \\
10.289
\end{tabular}} & \multirow{2}{*}{\begin{tabular}{|l|} 
Sig. \\
$.000^{\mathrm{a}}$
\end{tabular}} \\
\hline 1 & Regression & & & & & \\
\hline & Residual & 32.187 & 413 & .078 & & \\
\hline & Total & 36.998 & 419 & & & \\
\hline
\end{tabular}

\subsection{Age Demography}

The result of partial analysis based on age demography is presented in table 3 .

Table 3: Summary of Statistical Analysis Based on Age Demography

\begin{tabular}{|c|c|c|c|c|c|c|c|}
\hline \multirow{2}{*}{$\begin{array}{c}\text { Age } \\
\text { Demography }\end{array}$} & \multicolumn{6}{|c|}{ t-test } & \multirow[t]{2}{*}{ f-test } \\
\hline & Artifact & Haptic & Kinesics & Chronemics & Proxemics & Vocalic & \\
\hline Teenager & 0,019 & 0,043 & 0,029 & 0,209 & 0,323 & 0,537 & 0,003 \\
\hline Adult & 0,738 & 0,000 & 0,600 & 0,527 & 0,358 & 0,077 & 0,000 \\
\hline $\begin{array}{l}\text { Elderly and } \\
\text { the oldest }\end{array}$ & 0,078 & 0,022 & 0,520 & 0,568 & 0,182 & 0,972 & 0,063 \\
\hline
\end{tabular}

In terms of age demography, all age ranges of respondents were significantly influenced by haptic as naturally and culturally people feel comfortable with touching. However, chrenomics did not have any influence to the variables of age demography. For teenagers, artifact is the most significantly variable influence their satisfaction since they usually admire physician's performance and observes what physician's wear. For adult and elderly also the oldest haptic is the most significantly variable influence their satisfaction. Older patients need to be appreciated and warm hug that's why they don't observe any details of what physician wear. This finding is consistent with previous research such as Norbeg, Hollinger and Buschmann, McCann and McKenna in Gleeson and Timmins (2004) $)^{14}$ claiming that touch calms, reassures, shares warmth and provides stimulation to older people. Hall, Harrigan, and Rosenthal (1995) also explained that adult patient expected physician not talking too much and listening closely (Riggio and Feldman, 2005) ${ }^{15}$. 


\subsection{Gender Demography}

The result of partial analysis based on gender demography is illustrated in table 4.

Table 4: Summary of Statistical Analysis Based on Gender Demography

\begin{tabular}{|l|c|c|c|c|c|c|c|}
\hline \multirow{2}{*}{$\begin{array}{c}\text { Gender } \\
\text { Demography }\end{array}$} & \multicolumn{9}{|c|}{ t-test } & f-test \\
\cline { 2 - 7 } & Artifact & Haptic & Kinesics & Chronemics & Proxemics & Vocalic & \\
\hline Male & 0,793 & 0,055 & 0,948 & 0,107 & 0,002 & 0,088 & 0,000 \\
\hline Female & 0,007 & 0,000 & 0,460 & 0,334 & 0,324 & 0,005 & 0,000 \\
\hline
\end{tabular}

Satisfaction of both male and female are significantly influenced by haptic but proxemics also plays a role in giving patient's satisfaction. Besides that, vocalic and kinesics also influence male patient's satisfaction. With their braveness they can have an eye contact with physician. Commonly male patients are perfunctory to the physician treatment. Different with female patients that more sensitive with touch and feel comfortable with physician treatment. Female is more relax, expressive and has a strong interpersonal relationship than male (Herqutanto, 2011) ${ }^{17}$. Female observe the little things like the time physician come and give consultation, also the distance when physician stand around them.

\subsection{Ward's Classes Demography}

The result of partial analysis based on ward's class demography is indicated in table 5.

Table 5: Summary of Statistical Analysis Based on Ward's Classes Demography

\begin{tabular}{|l|c|c|c|c|c|c|c|}
\hline \multirow{2}{*}{$\begin{array}{c}\text { Ward's Classes } \\
\text { Demography }\end{array}$} & \multicolumn{9}{|c|}{ t-test } & f-test \\
\cline { 2 - 7 } & Artifact & Haptic & Kinesics & Chronemics & Proxemics & Vocalic & \\
\hline VIP & 0,160 & 0,370 & 0,736 & 0,057 & 0,230 & 0,124 & 0,092 \\
\hline First Class & 0,112 & 0,617 & 0,090 & 0,641 & 0,029 & 0,679 & 0,098 \\
\hline Second Class & 0,007 & 0,000 & 0,501 & 0,177 & 0,954 & 0,424 & 0,000 \\
\hline Third Class & 0,125 & 0,049 & 0,692 & 0,301 & 0,099 & 0,002 & 0,001 \\
\hline
\end{tabular}

In general, patients treated in the lowest class (third class) feel satisfied with the speed of physician's talks since physicians usually talk with moderate intonations, not too loud but not too weak, such that patients could easily understand information given by physicians. However, patients treated in the second class stated that touching has a significant influence to their satisfaction. The distance between physician and patients treated in the first class has significant influence to their satisfaction. Interestingly for patients treated in VIP class, there are no influenced variables of physician's nonverbal communication to their satisfaction. In most cases, VIP patients come from middle up economic family background and have many expectations such that it is difficult to fulfill their needs. Patients treated in the first or higher classes with more complete facilities tend to have higher expectations since they feel that they pay more expensive fees to obtain health services suitable with their expectations (Suratun, Manurung andSumartini, 2014) ${ }^{18}$.

\subsection{Ethnics Demography}

The result of partial analysis based on ethnics' demography is represented in table 6 .

Table 6: Summary of Statistical Analysis Based on Ethnics Demography

\begin{tabular}{|c|c|c|c|c|c|c|c|}
\hline \multirow{2}{*}{$\begin{array}{c}\text { Ethnics } \\
\text { Demography }\end{array}$} & \multicolumn{6}{|c|}{ t-test } & \multirow[t]{2}{*}{ f-test } \\
\hline & Artifact & Haptic & Kinesics & Chronemics & Proxemics & Vocalic & \\
\hline Bugis & 0,354 & 0,000 & 0,958 & 0,952 & 0,052 & 0,148 & 0,000 \\
\hline Makassar & 0,017 & 0,004 & 0,205 & 0,133 & 0,059 & 0,305 & 0,000 \\
\hline Others & 0,133 & 0,017 & 0,789 & 0,069 & 0,195 & 0,551 & 0,043 \\
\hline
\end{tabular}


All ethnics tend to be influenced by hapticto their satisfaction. In addition to artifact also significantly influences the satisfactory level of Makassar ethnics. They observe the punctuality of physician when having a consultation. Patients are influenced by artifacts since they more observe on the physical performanceof physician when talking.

\subsection{Education Demography}

The result of partial analysis based on education demography is illustrated in table 7.

Table 7: Summary of Statistical Analysis Based on Education Demography

\begin{tabular}{|c|c|c|c|c|c|c|c|}
\hline \multirow{2}{*}{$\begin{array}{c}\text { Education } \\
\text { Demography }\end{array}$} & \multicolumn{6}{|c|}{ t-test } & \multirow[t]{2}{*}{ f-test } \\
\hline & Artifact & Haptic & Kinesics & Chronemics & Proxemics & Vocalic & \\
\hline $\begin{array}{l}\text { Elementary } \\
\text { \&High School }\end{array}$ & 0,034 & 0,000 & 0,608 & 0,182 & 0,061 & 0,027 & 0,000 \\
\hline $\begin{array}{l}\text { Higher } \\
\text { Education }\end{array}$ & 0,398 & 0,014 & 0,374 & 0,071 & 0,000 & 0,340 & 0,000 \\
\hline
\end{tabular}

In the category of elementary and junior high schools, the most significant variable influencing patient's satisfaction is haptic. While in the category of higher education, the most significant variables influencing patient's satisfaction is proxemics since the higher the level of education, the more difficult to be satisfied with health service provided (Crow et al, 2002) $)^{19}$. According to Hanafi and Richard $(2012)^{20}$, people with higher education level have better knowledge such that they tend to accept and manage information easily. On the contrary, people with lower education level tend to be difficult to respond or communicate using higher level knowledge. Based on the research carried out by Lestari et al (2009) $)^{21}$, patients with lower education level tend to feel more satisfied easily while those having higher education level would have better knowledge to make justification or critics to health service provided.The presence of unsatisfied patients to the health service provided occurred due to higher level of their education such that they have better understanding on their rights.

\subsection{Occupation Demography}

The result of partial analysis based on occupation's demography is indicated in table 8.

Table 8: Summary of Statistical Analysis Based on Occupation Demography

\begin{tabular}{|c|c|c|c|c|c|c|c|}
\hline \multirow{2}{*}{$\begin{array}{l}\text { Occupation } \\
\text { Demography }\end{array}$} & \multicolumn{6}{|c|}{ t-test } & \multirow[t]{2}{*}{ f-test } \\
\hline & Artifact & Haptic & Kinesics & Chronemics & Proxemics & Vocalic & \\
\hline Unemployed & 0,002 & 0,000 & 0,098 & 0,224 & 0,541 & 0,007 & 0,000 \\
\hline Public Sector & 0,873 & 0,018 & 0,405 & 0,545 & 0,162 & 0,141 & 0,014 \\
\hline Private Sector & 0,932 & 0,796 & 0,403 & 0,532 & 0,000 & 0,391 & 0,000 \\
\hline
\end{tabular}

Unemployed and civil servant patients tend to be satisfied with physician's touching while those who work in private sectors are influenced by the distance between physician and patients to fulfill their satisfaction. In Indonesia, people working in the public sectors or civil servants tend to have higher incomes than those who work in private sectors. According to Crow et al $(2002)^{22}$, patients having high incomes tend to be more satisfied with physician's communication skills. With better and effective communication, they expect to plan health program for their future. However, patients with lower incomes reported that many problems encountered during their staying in hospital.

Employed patients always want to make sure about their health condition to continue performing their occupations. As a result, it is important for them to perform physical contact with physician during consultation to assure their health. They feel satisfied since the physician pay attention to them. Unemployed 
patients, mostly household wives and retired patients, feel satisfied with physician's service using physical contacts during consultation as a form of a friendship between physician and patient.

\section{CONCLUSION}

Previous works showed significant influences of nonverbal communication to patient's satisfaction. However, little attention focused on the demography of patients. This research demonstrates that demography plays a significant role to moderate the influences of physician nonverbal communication to patient's satisfaction. Understanding the way the demographer think and perceive would be useful to design nonverbal communication style to encourage positive feelings and emotions of patients that subsequently lead to optimum health treatment.

\section{REFERENCES}

Lobb E. A., Butow P. N., Kenny D. T., and Tattersall H. N. (1999), Communicating Prognosis in Early Breast Cancer: Do Women Understand the Language Used?, Medical Journal of Australia, 171 (6), p.290-294.

Von Guten C. F., Ferris F. D., and Emanuel L. L. (2000), The Patient-Physician Relationship “Ensuring Competencies in End-of-Life Care: Communication and Relational Skills", The Journal of the American Medical Association, 284 (23), p.3051-3057.

Sudirman Indrianty. (2012), Understanding the Dynamic Interaction within Indonesia Healthcare Competition, European Journal of Business and Management, 4 (11), p.94-100.

Friedman. (1979),Nonverbal Communication between Patient and Medical Practitioner, Journal of Social Issue, p.82-89.

Ambady Nalini et al. (2002), Physical Therapists' Nonverbal Communication Predicts Geriatric Patients' Health Outcome, American Phychological Association.

Griffith et al. (2003), House Staff Nonverbal Communication Skills and Standardized Patient Satisfaction, Journal List J gen Intern Med, 18 (3), p.170-174.

Sudirman Indrianty. (2002), Penerapan Orientasi Pasar dalam Pelayanan Jasa RS di Kota Makassar ditinjau dari Strategi Prospectors, Analyzers, dan Defenders, Makassar. UniversitasHasanuddin.

Sudirman Indrianty. (2012), Hubungan antara Kepuasan Pasien, Loyalitas, dan Kinerja Organisasi, Jurnal Administrasi Negara Edisi III.

Konsil Kedokteran Indonesia (KKI).(2012), Standar Kompetensi Dokter Indonesia, Jakarta. Konsil Kedokteran Indonesia.

Watson M. J. (1988), New Dimension of Human Caring Theory, Nursing Science Quarterly, 1 (4), p.175-181.

Mehrabian A. (1972), Nonverbal Communication. In J. K. Cole (Ed.), Nebraskan Symposium on Motivation, 1971, Lincoln, NE: University of Nebraska Press, 19, p.107-161.

Leather D. G.(1976), Nonverbal Communication Systems, USA. Allyn and Bacon Inc.

Morris (1977) in Liliweri A. (2004), Dasar-Dasar Komunikasi antar Budaya, Yogyakarta. Pustaka Pelajar.

Khan F.F.H. et al. (2014), Patient Attitudes toward Physician Nonverbal Behavior during Consultancy: Result from a Developing Country, ISRN Family Medicine.

Glesson M. and Timmins F. (2004), Touch: A Fundamental Aspect of Communication with Older People Experiencing Dementia, Nursing Older People, 16 (2).

Riggio R. E. and Feldman R.S. (2005), Applications of Nonverbal Communication, USA.Lawrence Erlbaum Associates.

Herqutanto et al. (2011).Pengetahuan dan Keterampilan Komunikasi Dokter Pasien dan Faktor-Faktor yang Mempengaruhinya, Indonesian Medical Association, 61 (5).

Suratun, Manurung S., and Sumartini M. (2014), Hubungan antara Pendidikan Kesehatan dan Kepuasan Pasien Diabetus Mellitus di RuangRawat Rumah Sakit Persahabatan Tahun 2011, Jurnal IImiah WIDYA, 2 (1), p.41-47.

Crow R. et al. (2002), The Measurement of Satisfaction with Healthcare: Implications for Practice from a Systematic Review of the Literature, Health Technology Assessment, 6 (32). 
Hanafi Imam and Richard S. D. (2012), Keterampilan Komunikasi Interpersonal Perawat Berpengaruh Peningkatan Kepuasan Pasien, Kediri. Jurnal STIKES, 5 (2).

Lestari et al. (2009), Analisa Faktor Penentu Tingkat Kepuasan Pasien di Rumah Sakit PKU Muhammadiyah Bantul, Jurnal Kedokteran dan Kesehatan Indonesia.

Mast M.S., Hall J.A., Klockner C. and Choi E.(2008), Physician Gender Affects How Physician Nonverbal Behavior is Related to Patients Satisfaction, Medical Care, 46 (12), p.1212-1218. 